International Journal of Agriculture, Environment and Bioresearch

Vol. 5, No. 04; 2020

ISSN: $2456-8643$

\title{
YIELD AND YIELD COMPONENTS OF MAIZE (Zea mays L.) AS INFLUENCED BY WEED CONTROL TREATMENTS AND SHEEP MANURE APPLICATION IN ANYIGBA, NIGERIA
}

\author{
Agahiu, Attai Emmanuel \\ Department of Crop Production, Faculty of Agriculture,Kogi State University, Anyigba
}

https://doi.org/10.35410/IJAEB.2020.5539

\begin{abstract}
Field experiments were conducted during the 2015 and 2016 cropping seasons at the Students Research and Demonstration Farm, Faculty of Agriculture, Kogi State University, Anyigba to evaluate the effects of weed control treatments and sheep manure application on the yield and yield components of maize. The experiments were laid out in a split plot in a randomized complete block design and replicated three times, with the weed control treatments allocated to the main plots while the manure treatments were allocated to the sub plots. The trials had eight weed control treatments in each cropping season consisting of Codal Gold,a formulation of metalachlor + prometryne applied at 1.5 and $2.0 \mathrm{~kg}$ a.; $/$ ha; atrazine + metolachlor (Primextra Gold) at 1.5 and $2.3 \mathrm{~kg}$ a.i/ha; atrazine + bromoxynil at 2.1 and $2.3 \mathrm{~kg}$ a.i/ha; hoe weeding at 4 and 8 weeks after sowing (WAS) and a weedy check with four-rates of sheep manure at $0,2,4$ and $6 \mathrm{t} / \mathrm{ha}$. In these trials, plots treated with $2.3 \mathrm{~kg}$ a.i/ha of atrazine + bromoxynil had the least weed cover and weed dry weight which compared favourably with the results obtained in plots treated with atrazine + metolachlor at $2.3 \mathrm{~kg}$ a.i/ha in these parameters. The weedy check consistently produced the highest weed cover score and weed dry weight in the two years of study. Maize plants in plots treated with atrazine +bromoxynil at $2.3 \mathrm{~kg}$ a.i/ha had higher stem girth, longer and larger cobs and the highest grain yield in comparison to all other treatments applied in the trials. In a similar vein, plots treated with 6t/ha of sheep manure produced longer, larger cobs as well as the highest grain field whereas, plots that did not receive manure treatment gave the least in these parameters similar to the weedy check plots.
\end{abstract}

Keywords: Weed control, manure, crop vigour, cob, grain yield.

\section{INTRODUCTION}

Maize (Zea mays L.) is the third most important cereal crop of the world after wheat and rice with a world total production of 990 million tons in 2014 [1]. According to [2], it is a major cereal crop third in world production after wheat and rice. It is a staple food and a source of raw material for industries and is fast replacing other cereal crops such as rice, guineacorn and millet in Nigeria. Maize is a major crop in Nigeria and its annual grain production is approximately 10.7 million metric tons from a land area estimated at 5.8 million ha [3]. Nigeria produced about 11.3 million tons in 2013, making it the largest producer in Africa [4]. In spite of the great potentials for food, fodder as well as for industrial purposes, maize is sensitive to weed 
infestation throughout its life cycle. In Nigeria, losses of up to $80 \%$ in the potential grain yield of maize have been attributed to unchecked weed growth [5]. Maize production is greatly constrained by a number of factors among which are the use of low yielding local varieties, low soil fertility status, drought, pests, diseases and weed menace. According to [6], low organic matter content, low inherent soil fertility and low CEC characterize the Nigeria soil with nitrogen and phosphorus as the most limiting elements in the soil. And of all the constraints limiting maize production in Nigeria, weeds are the most deleterious causing 69-92\% reduction in grain yield $[7,8,9]$. Weed inference reduces maize grain yield by 40 to $100 \%$ depending on the ecosystem, weed spectra and the cultural practices [10, 11]. Therefore, weed management remains a major factor in the production of maize wherever it is being grown. Considering the high cost of inorganic fertilizer vis-à-vis its unavailability at the time it is most needed by farmers during the cropping season, it becomes very necessary that an alternative avenue be created towards enhancing the fertility status of the soil so as to ensure sustainable crop production. The outcry coming from farmers on the ineffectiveness of some herbicides in providing a long season and broad spectrum control of weeds in maize farm is of concern to the researcher. Therefore, the objective of this trial was to evaluate the effects of some weed control treatments and sheep manure on the performance of maize in Anyigba

\section{MATERIALS AND METHODS}

The experiments were conducted during the 2015 and 2016 cropping seasons at the Students Research and Demonstration Farm, Faculty of Agriculture, Kogi State University, Anyigba ( $07^{0}$ $\left.29 \mathrm{~N}, 07^{0} 11^{\prime} \mathrm{E}\right)$ to evaluate the effects of weed control treatments and the application of sheep manure on the yield and yield components of maize in the derived guinea savanna zone of Nigeria. The treatments were eight consisting of Codal Gold $412 \mathrm{EC}$, a commercial formulation of metolachlor + prometryne at 1.5 and $2.0 \mathrm{Kg}$ a.i/ha, primextra Gold (atrazine + metolachlor) applied at 1.5 and $2.3 \mathrm{~kg}$ a.i/ha; atrazine + bromoxynil at 2.1 and $2.3 \mathrm{~kg}$ a.i/ha, hoe weeding at 4 and 8 weeks after sowing (WAS) and a weedy check with four rates of sheep manure at $0,2,4$ and 6t/ha. The treatments were arranged in a factorial pattern and laid out in a split plot in Randomized complete block design and replicated three times. The weed control treatments were assigned to the main plots while the manure treatments were allocated to the sub-plots. The soil $(0-20 \mathrm{~cm})$ on which the study was carried out was analyzed for its physico-chemical characteristics in the Department of soil and Environmental management, Kogi State University, Anyigba. TZE composite 3C, a late maturing maize variety obtained from the Ministry of Agriculture, Lokoja, Kogi State was used in this trial. The field was cleared of the initial vegetation after identifying the commonest weed species vis-a-vis their relative abundance. It was then later ploughed, harrowed and ridged at $75 \mathrm{~cm}$ inter row spacing followed by making out of the plots. Each gross plot was $4 \mathrm{~m} \times 4 \mathrm{~m}\left(16 \mathrm{~m}^{2}\right)$ while the net plot was $3 \mathrm{~m} \mathrm{x} 4 \mathrm{~m}\left(12 \mathrm{~cm}^{2}\right)$. Maize seeds were sown on the 15th June,2015 and 26th June 2016. The seeds were earlier dressed with Apronstar (methylthiuram + metalaxy1 + carboxin) at the rate of $3.0 \mathrm{~kg}$ seed per $10 \mathrm{~g}$ sachet of the chemical to give protection to the seeds against soil borne pests and pathogens. Two maize seeds were sown per hole and the seedlings thinned to one plant per stand at 2 WAS. The intra-row used was $25 \mathrm{~cm}$ giving a total population of 53,333 plants/ha. The sheep manure was incorporated into the soil two weeks before planting was done. Urea fertilizer was applied four weeks after sowing as sheep manure is low in nitrogen. In each year of the trial, hoe 
weeding was carried out twice at 4 and 8 WAS in the appropriate plots. Herbicides were applied by the use of a CP3 knapsack sprayer calibrated to deliver $242 \mathrm{~L} /$ ha of the spray solution. Data were collected on the following parameters for analysis. The data collected include:

Days to $50 \%$ tasselling: This was obtained by the number of days from planting to the day half the number of plants had produced tassels.

Weed Cover score: -This was visually assessed at 6 and 12 WAS using a scale of 1 to 10 where 1 represented no weed cover and 10 represented total weed cover.

Weed dry weight: This was obtained by taking weed samples at random using a $1 \mathrm{~m}^{2}$ quadrant in all the plots at 6 and 12 WAS. The weeds were cleaned to ensure that there were no deposits of soil particles on them and then oven dried to constant weight. The dry weight was then recorded. Crop Vigour score: The crop vigour score was assessed visually at 6 and 12 WAS by using a scale of 1 to 10 where 1 represented completely dead plants and 10 represented most vigorous plants. Plant height $(\mathrm{cm})$ :

Plant height at harvest (12WAS) was measured from the ground level to the tip of flag leaf and tassel at maturity stage by the use of a meter rule.

Stem girth (cm): Measurement of stem girth at harvest was done at $10 \mathrm{~cm}$ above ground level on five tagged plants by the use of a venier caliper and then averaged to obtain the mean value per plant per plot.

Cob length $(\mathrm{cm})$ : This was obtained by the use of a meter rule.

Grain yield (Kg/ha): The cobs harvested from the net plots were dehusked and shelled. The clean grains were weighed per plot and expressed in kilo grams per hectare. Data collected were subjected to analysis of variance (ANOVA) and significant differences among treatment means were compared by the use of Duncan's Multiple Range Test (DMRT).

\section{RESULTS}

Table 1 shows that the textural class of the soils of the experimental sites was loam which is suitable for production of maize. Dominant weed species present and identified at the experimental sites and their level of infestation are shown in Table 2. The weed species were morning glory, copper leaf plant, black sesame, stinking cassia, red spiderling, hedgehog grass, fingergrass, bullgrass, congograss, guineagrass and cat's tailgrass. 
International Journal of Agriculture, Environment and Bioresearch

Vol. 5, No. 04; 2020

ISSN: $2456-8643$

Table 1: Physical and chemical properties of the soil (0-20) collected from the experimental sites in 2015 and 2016 cropping seasons

\begin{tabular}{|lll|}
\hline Physical Properties & 2015 & 2016 \\
\hline Sand $(\mathrm{g} / \mathrm{kg})$ & 764 & 400 \\
Silt $(\mathrm{g} / \mathrm{kg})$ & 56 & 320 \\
Clay $(\mathrm{g} / \mathrm{kg})$ & 51 & 225 \\
Textural class & Loam & Loam \\
Chemical Properties & & \\
$\mathrm{pH}\left(\mathrm{H}_{2} 0\right)$ & 6.5 & 6.0 \\
Total Nitrogen $(\mathrm{g} / \mathrm{kg})$ & 0.46 & 0.42 \\
Available P $(\mathrm{mg} / \mathrm{kg})$ & 0.30 & 1.91 \\
Organic carbon $(\mathrm{g} / \mathrm{kg})$ & 0.76 & 0.73 \\
Exchangeable cation $(\mathrm{Cmol} / \mathrm{kg})$ & & \\
Ca & 4.20 & 4.0 \\
Na & 0.19 & 0.21 \\
Mg & 1.65 & 0.24 \\
$\mathrm{~K}$ & 1.51 & 1.68 \\
\hline
\end{tabular}

Table 2: Common weed species and their level of infestation prior to land preparation at Anyigba in 2015 and 2016 cropping seasons

\begin{tabular}{|llllc|}
\hline Weed species & Common name & Family & \multicolumn{2}{c|}{ Level of infestation } \\
& & & 2015 & 2016 \\
\hline Ipomoea involucrate & Morning glory weed & Convolvulaceae & + & + \\
Acalypha fimbriata & Copper leaf plant & Euphorbiaceae & ++ & ++ \\
Hyptis spicifera & Black sesame & Lamiaceae & + & +++ \\
Senna hirsute & Stinking cassia & Caesapinioideae & + & ++
\end{tabular}


Vol. 5, No. 04; 2020

ISSN: 2456-8643

\begin{tabular}{|c|c|c|c|c|}
\hline Boerhavia diffusa & Red spiderling & Nyctaginaceae & +++ & ++ \\
\hline Cenchrus biflorus & Hedgehog grass & Poaceae & +++ & ++ \\
\hline Chloris pilosa & Fingergrass & Poaceae & +++ & +++ \\
\hline Eleusine jndica & Bullgrass & Poaceae & +++ & +++ \\
\hline Eragrostis tenella & Bug's egggrass & Poaceae & +++ & +++ \\
\hline Imperata cylindrical & Congograss & Poaceae & + & + \\
\hline Panicum maximum & Guineagrass & Poaceae & ++ & ++ \\
\hline Sporobolus pyramidalis & Cat's tailgrass & Poaceae & + & ++ \\
\hline $\begin{array}{l}+=\text { mild infestation } \\
++=\text { moderate infestation } \\
+++=\text { high infestation }\end{array}$ & & & & \\
\hline
\end{tabular}

Number of days to $50 \%$ tasselling was increased by all treatments in both seasons except Codal Gold at both rates. At these rates in this treatment the number of days to $50 \%$ tasselling was reduced. It took plants in plots treated with $2.0 \mathrm{~kg}$ a.i/ha of Codal Gold 86 days to attain $50 \%$ tasselling status (Table 3). Results in the years of study as well as in the combined analysis indicated that the highest weed cover was obtained in the weedy check plots with the mean values of 9.7 and 9.2 at 6 and 12 WAS respectively (Table 4). Plots treated with Codal Gold at $2.0 \mathrm{~kg}$ a.i/ha; atrazine + metolachlor and atrazine + bromoxynil at $2.3 \mathrm{~kg}$ a.i/ha each recorded the least weed cover at 6 WAS in 2015 cropping season. In 2016 at 12 WAS, least weed cover was achieved in plots that received atrazine + bromoxynil at $2.3 \mathrm{~kg}$ a.i/ha which was comparable to that obtained in plots treated with atrazine + metolachlor and atrazine + bromoxynil at 2.3 and $2.1 \mathrm{~kg}$ a.i/ha respectively. Weed cover was least in plots that did not receive sheep manure. The mean weed cover scores in those plots for the two years were 3.2 and 3.4 at 6 and 12 WAS respectively. The application of sheep manure at $6 \mathrm{t} / \mathrm{ha}$ resulted into the highest weed cover in the two years of study.

Table 3: Effect of weed control treatments and sheep manure on days to $50 \%$ tasselling in maize at Anyigba during 2015 and 2016 cropping seasons

\begin{tabular}{|llllll|}
\hline $\begin{array}{l}\text { Weed control } \\
\text { treatments }\end{array}$ & (WC) & Rate (kg a.i/ha) & $\begin{array}{l}\text { Days to 50\% } \\
\text { tasselling 2015 }\end{array}$ & $\begin{array}{l}\text { Days to 50\% } \\
\text { tasselling 2016 }\end{array}$ & Mean \\
\hline Codal Gold & 1.5 & $89^{\mathrm{ab}}$ & $88^{\mathrm{ab}}$ & $88.5^{\mathrm{ab}}$ \\
Codal Gold & 2.0 & $87^{\mathrm{ab}}$ & $86^{\mathrm{ab}}$ & $86.5^{\mathrm{ab}}$
\end{tabular}


Vol. 5, No. 04; 2020

ISSN: $2456-8643$

\begin{tabular}{|lllll|}
\hline Atrazine +Metolachlor & 1.5 & $91^{\mathrm{a}}$ & $92^{\mathrm{a}}$ & $91.5^{\mathrm{a}}$ \\
Atrazine + Metolachlor & 2.3 & $90^{\mathrm{a}}$ & $92^{\mathrm{a}}$ & $91.0^{\mathrm{a}}$ \\
Atrazine +Bromoxynil & 2.1 & $90^{\mathrm{a}}$ & $93^{\mathrm{a}}$ & $91.5^{\mathrm{a}}$ \\
Atrazine + Bromoxynil & 2.3 & $92^{\mathrm{a}}$ & $90^{\mathrm{a}}$ & $91.0^{\mathrm{a}}$ \\
Hoe weeding at 4 and 8 & $91^{\mathrm{a}}$ & $92^{\mathrm{a}}$ & $91.5^{\mathrm{a}}$ \\
WAS & & & $90.5^{\mathrm{a}}$ \\
Weedy check & & $90^{\mathrm{a}}$ & $91^{\mathrm{a}}$ & 0.82 \\
SE \pm & 0.51 & 1.03 & \\
Sheep manure (SM) & $\mathrm{t} / \mathrm{ha}$ & & & $93.5^{\mathrm{a}}$ \\
& 0 & $93^{\mathrm{a}}$ & $94^{\mathrm{a}}$ & $90.5^{\mathrm{a}}$ \\
& 2 & $91^{\mathrm{a}}$ & $90^{\mathrm{a}}$ & $90.0^{\mathrm{a}}$ \\
& 4 & $90^{\mathrm{a}}$ & $90^{\mathrm{a}}$ & $91.0^{\mathrm{a}}$ \\
SE \pm & $90^{\mathrm{a}}$ & $92^{\mathrm{a}}$ & 0.52 \\
Interaction & 6 & 0.53 & 0.51 & \\
WC*SM & & & & $\mathrm{NS}$ \\
\hline $\begin{array}{l}\text { Means in a column of any set of treatments followed by dissimilar letter(s) are significantly different } \\
\text { at } \mathrm{p} \leq 0.05 \text { using DMRT }\end{array}$ & & & & \\
& & & & \\
\hline
\end{tabular}

Table 4. Effect of weed control treatments and sheep manure on weed cover in maize at Anyigba during 2015 and 2016 cropping seasons

\begin{tabular}{|llllllll|}
\hline $\begin{array}{l}\text { Weed control } \\
\text { (WC) } \\
\text { treatments }\end{array}$ & $\begin{array}{l}\text { Rate (kg } \\
\text { a.i/ha) }\end{array}$ & $\begin{array}{l}\text { Weed cover } \\
\text { 6WAS 2015 }\end{array}$ & $\begin{array}{l}\text { Weed cover } \\
\text { 6WAS 2016 }\end{array}$ & Mean & Weed cover & Weed cover & Mean \\
\hline Codal Gold & 1.5 & $2.4^{\mathrm{bc}}$ & $2.5^{\mathrm{bc}}$ & $2.5^{\mathrm{bc}}$ & $2.1^{\mathrm{bc}}$ & $2.3^{\mathrm{bc}}$ & $2.2^{\mathrm{bc}}$ \\
\hline
\end{tabular}


Vol. 5, No. 04; 2020

ISSN: $2456-8643$

\begin{tabular}{|c|c|c|c|c|c|c|c|}
\hline Codal Gold & 2.0 & $1.0^{\mathrm{c}}$ & $1.2^{\mathrm{c}}$ & $1.1^{\mathrm{c}}$ & $2.0^{\mathrm{bc}}$ & $1.6^{\mathrm{c}}$ & $1.8^{\mathrm{c}}$ \\
\hline $\begin{array}{l}\text { Atrazine } \\
+ \text { Metolachlor }\end{array}$ & 1.5 & $2.3^{\mathrm{bc}}$ & $2.4^{\mathrm{bc}}$ & $2.4^{\mathrm{bc}}$ & $2.1^{\mathrm{bc}}$ & $2.3^{\mathrm{bc}}$ & $2.2^{\mathrm{bc}}$ \\
\hline $\begin{array}{l}\text { Atrazine } \\
+ \text { Metolachlor }\end{array}$ & 2.3 & $1.1^{\mathrm{c}}$ & $1.1^{\mathrm{c}}$ & $1.1^{\mathrm{c}}$ & $1.3^{\mathrm{c}}$ & $1.2^{\mathrm{c}}$ & $1.3^{\mathrm{c}}$ \\
\hline $\begin{array}{l}\text { Atrazine } \\
+ \text { Bromoxynil }\end{array}$ & 2.1 & $1.2^{\mathrm{c}}$ & $1.2^{\mathrm{c}}$ & $1.2^{\mathrm{c}}$ & $1.3 \mathrm{c}$ & $1.3^{\mathrm{c}}$ & $1.3^{\mathrm{c}}$ \\
\hline $\begin{array}{l}\text { Atrazine } \\
\text { Bromoxynil }\end{array}$ & 2.3 & $1.0^{\mathrm{c}}$ & $1.0^{\mathrm{c}}$ & $1.0^{\mathrm{c}}$ & $1.0^{\mathrm{c}}$ & $1.1^{\mathrm{c}}$ & $1.1^{\mathrm{c}}$ \\
\hline $\begin{array}{l}\text { Hoe weeding } \\
\text { at } 4 \text { and } 8 \\
\text { WAS }\end{array}$ & & $3.1^{\mathrm{b}}$ & $2.8^{\mathrm{b}}$ & $3.0^{\mathrm{b}}$ & $3.0^{\mathrm{b}}$ & $2.1^{\mathrm{b}}$ & $2.6^{\mathrm{b}}$ \\
\hline Weedy check & & $9.7^{\mathrm{a}}$ & $9.7^{\mathrm{a}}$ & $9.7^{\mathrm{a}}$ & $9.0^{\mathrm{a}}$ & $9.3^{\mathrm{a}}$ & $9.2^{\mathrm{a}}$ \\
\hline $\mathrm{SE} \pm$ & & 0.11 & 0.10 & 0.05 & 0.10 & 0.12 & 0.06 \\
\hline \multirow{5}{*}{$\begin{array}{l}\text { Sheep } \\
\text { manure (SM) }\end{array}$} & $\mathrm{t} / \mathrm{ha}$ & & & & & & \\
\hline & 0 & $3.3^{\mathrm{b}}$ & $3.0^{\mathrm{b}}$ & $3.2^{\mathrm{b}}$ & $3.2^{\mathrm{b}}$ & $3.6^{\mathrm{b}}$ & $3.4^{\mathrm{b}}$ \\
\hline & 2 & $4.2^{\mathrm{ab}}$ & $4.0^{\mathrm{a}}$ & $4.1^{\mathrm{b}}$ & $3.9^{\mathrm{a}}$ & $4.3^{\mathrm{a}}$ & $4.1^{\mathrm{a}}$ \\
\hline & 4 & $4.8^{\mathrm{a}}$ & $4.5^{\mathrm{a}}$ & $4.7^{\mathrm{a}}$ & $4.2^{\mathrm{a}}$ & $4.8^{\mathrm{a}}$ & $4.5^{\mathrm{a}}$ \\
\hline & 6 & $5.7^{\mathrm{a}}$ & $5.2^{\mathrm{a}}$ & $5.5^{\mathrm{a}}$ & $4.9^{\mathrm{a}}$ & $5.3^{\mathrm{a}}$ & $5.1^{\mathrm{a}}$ \\
\hline $\mathrm{SE} \pm$ & & 0.11 & 0.11 & 0.04 & 0.05 & 0.09 & 0.04 \\
\hline \multicolumn{8}{|l|}{ Interaction } \\
\hline $\mathrm{WC} * \mathrm{SM}$ & & NS & NS & NS & NS & NS & NS \\
\hline
\end{tabular}

Means in a column of any set of treatments followed by dissimilar letter(s) are significantly different at $\mathrm{p} \leq 0.05$ using DMRT

Plots treated with atrazine + bromoxymil at $2.3 \mathrm{~kg}$ a.i/ha recorded the lowest weed dry weight at both 6 and 12 WAS (Table 5). In this treatment, the mean weed dry weight at 6 WAS for the two years of study was $14.3 \mathrm{~kg} / \mathrm{ha}$ while at $12 \mathrm{WAS}$, it was $22.2 \mathrm{~kg} / \mathrm{ha}$. There was a significant effect of sheep manure application on weed dry weight in maize in the study area. In both sampling periods (6 and $12 \mathrm{WAS}$ ), the highest weed dry weight was recorded in plots that received $6 \mathrm{t} / \mathrm{ha}$ of 
sheep manure. Plots that did not receive sheep manure had the least weed dry weight at 6 and 12 WAS. The Highest weed dry weight at 6 and 12 WAS was obtained in the weedy check plots.

As shown in Table 6, crop vigour score was significantly $(\mathrm{P}<0.05)$ higher in plots that received $2.3 \mathrm{~kg} \mathrm{a}$.i/ha of atrazine + bromoxynil than in any other treatments applied. It resulted to the highest crop viguor score at both 6 and 12 WAS with the mean values of 9.1 and 8.8 respectively. Crop vigour in plots treated with $2.3 \mathrm{~kg}$ a.i/ha of atrazine + bromoxynil compared favourably with that obtained in plots that received atrazine + metolachlor at $2.3 \mathrm{~kg}$ a. $/$ ha and Codal Gold at $2.0 \mathrm{~kg}$ a.i/ha particularly at $12 \mathrm{WAS}$. The application of sheep manure at $6 \mathrm{t} / \mathrm{ha}$ gave the highest crop vigour at 6 and 12 WAS. The weedy check plots recorded the lowest crop vigour with mean values of 1.4 and 1.2 at 6 and 12 WAS respectively.

Table 7 shows the effect of weed control treatments and sheep manure application on plant height and stem girth of maize. The weedy check plots recorded the shortest plants in both 2015 and 2016 cropping seasons. Maize plants were comparatively shorter in 2016 than in 2015 though the difference was not statistically significant. Similarly, plots that did not receive sheep manure produced the shortest maize plants: Maize plants were taller in plots treated with 4 or $6 \mathrm{t} / \mathrm{ha}$ of sheep manure in both years.

Table 5. Effect of weed control treatments and sheep manure on weed dry weight in maize at Anyigba during 2015 and 2016 cropping seasons

\begin{tabular}{|c|c|c|c|c|c|c|c|}
\hline $\begin{array}{l}\text { Weed control } \\
\text { (WC) } \\
\text { treatments }\end{array}$ & $\begin{array}{l}\text { Rate } \\
\text { (kga.i/ha) }\end{array}$ & $\begin{array}{l}\text { WDW(kg/ha) } \\
\text { 6WAS } 2015\end{array}$ & $\begin{array}{l}\text { WDW(kg/ha) } \\
\text { 6WAS } 2016\end{array}$ & Mean & $\begin{array}{l}\text { WDW(kg/ha) } \\
\text { 12WAS } 2015\end{array}$ & $\begin{array}{l}\text { WDW(kg/ha) } \\
\text { 12WAS } 2016\end{array}$ & Mean \\
\hline Codal Gold & 1.5 & $17.0^{c}$ & $19.0^{c}$ & $18.0^{c}$ & $34.3^{c}$ & $36.4^{c}$ & $35.4^{\mathrm{c}}$ \\
\hline Codal G & 2.0 & $15.4^{\mathrm{cd}}$ & $16.0^{\mathrm{cd}}$ & $15.7^{\mathrm{d}}$ & $24.2^{\mathrm{e}}$ & $24.3^{\mathrm{f}}$ & $24.3^{\mathrm{e}}$ \\
\hline $\begin{array}{l}\text { Atrazine } \\
+ \text { Metolachlor }\end{array}$ & 1.5 & $16.2^{\mathrm{cd}}$ & $18.3^{c}$ & $17.3 \mathrm{c}$ & $30.8^{d}$ & $32.0^{\mathrm{d}}$ & $31.4^{\mathrm{d}}$ \\
\hline $\begin{array}{l}\text { Atrazine+ } \\
\text { Metolachlor }\end{array}$ & 2.3 & $15.3^{c}$ & $16.2^{\mathrm{cd}}$ & $15.8^{d}$ & $23.1^{\mathrm{e}}$ & $24.0^{\mathrm{f}}$ & $23.6^{\mathrm{f}}$ \\
\hline $\begin{array}{l}\text { Atrazine } \\
+ \text { Bromoxynil }\end{array}$ & 2.1 & $16.4^{c}$ & $18.1^{c}$ & $17.3^{c}$ & $25.0^{\mathrm{e}}$ & $27.3^{\mathrm{e}}$ & $26.2^{\mathrm{e}}$ \\
\hline $\begin{array}{l}\text { Atrazine+ } \\
\text { Bromoxynil }\end{array}$ & 2.3 & $14.1^{\mathrm{e}}$ & $14.4^{\mathrm{d}}$ & $14.3^{\mathrm{d}}$ & $20.6^{\mathrm{f}}$ & $23.7^{f}$ & $22.2^{f}$ \\
\hline $\begin{array}{l}\text { Hoe weeding } \\
\text { at } 4 \text { and } 8 \\
\text { WAS }\end{array}$ & & $20.6^{\mathrm{b}}$ & $24.0^{\mathrm{b}}$ & $22.3^{\mathrm{b}}$ & $40.8^{b}$ & $40.3^{\mathrm{b}}$ & $40.6^{\mathrm{b}}$ \\
\hline Weedy check & & $72.4^{\mathrm{a}}$ & $68.7^{\mathrm{a}}$ & $70.6^{\mathrm{a}}$ & $98.5^{\mathrm{a}}$ & $102.7^{\mathrm{a}}$ & $101.0^{\mathrm{a}}$ \\
\hline
\end{tabular}


Vol. 5, No. 04; 2020

ISSN: 2456-8643

$\mathrm{SE} \pm$

0.51

0.49

0.50

0.76

0.79

0.77

Sheep t/ha

manure (SM)

\begin{tabular}{|c|c|c|c|c|c|c|c|}
\hline & 0 & $24.1^{\mathrm{b}}$ & $22.2^{\mathrm{d}}$ & $23.2^{\mathrm{c}}$ & $41.2^{\mathrm{b}}$ & $44.2^{\mathrm{b}}$ & $43.0^{\mathrm{b}}$ \\
\hline & 2 & $26.3^{\mathrm{b}}$ & $25.8^{\mathrm{c}}$ & $26.1^{\mathrm{c}}$ & $43.9^{\mathrm{a}}$ & $44.1^{\mathrm{b}}$ & $44.0^{\mathrm{b}}$ \\
\hline & 4 & $30.2^{\mathrm{a}}$ & $33.6^{\mathrm{b}}$ & $32.0^{\mathrm{b}}$ & $45.2^{\mathrm{a}}$ & $47.0^{\mathrm{a}}$ & $46.1^{\mathrm{a}}$ \\
\hline & 6 & $34.4^{\mathrm{a}}$ & $39.8^{\mathrm{a}}$ & $37.1^{\mathrm{a}}$ & $46.4^{\mathrm{a}}$ & $47.6^{\mathrm{a}}$ & $47.0^{\mathrm{a}}$ \\
\hline $\mathrm{SE} \pm$ & & 0.38 & 0.41 & 0.35 & 0.48 & 0.52 & 0.50 \\
\hline eraction & & & & & & & \\
\hline $\mathrm{WC} * \mathrm{SM}$ & & NS & NS & NS & NS & NS & NS \\
\hline
\end{tabular}

WDW: Weed dry weight, Means in a column of any set of treatments followed by dissimilar letter(s) are significantly different at $\mathrm{p} \leq 0.05$ using DMRT

Table 6. Effect of weed control treatments and sheep manure on crop vigour of maize at Anyigba during 2015 and 2016 cropping seasons

\begin{tabular}{|c|c|c|c|c|c|c|c|}
\hline \multirow[t]{2}{*}{$\begin{array}{l}\text { Weed control } \\
\text { (WC) treatments }\end{array}$} & \multirow{2}{*}{$\begin{array}{l}\text { Rate } \\
\text { (kga.i/ha }\end{array}$} & \multirow{2}{*}{$\begin{array}{l}\text { Crop vigour } \\
\text { 6WAS } \\
2015\end{array}$} & \multirow{2}{*}{$\begin{array}{l}\text { Crop vigour } \\
\text { 6WAS } \\
2016\end{array}$} & \multirow[t]{2}{*}{ Mean } & \multirow{2}{*}{$\begin{array}{l}\text { Crop vigour } \\
12 \text { WAS } \\
2015\end{array}$} & \multirow{2}{*}{$\begin{array}{l}\text { Crop vigour } \\
12 \text { WAS } \\
2016\end{array}$} & \multirow[t]{2}{*}{ Mean } \\
\hline & & & & & & & \\
\hline Codal Gold & 1.5 & $5.5^{\mathrm{b}}$ & $4.3^{\mathrm{b}}$ & $4.9^{\mathrm{b}}$ & $4.8^{\mathrm{bc}}$ & $4.6^{\mathrm{b}}$ & $4.7^{\mathrm{b}}$ \\
\hline Codal Gold & 2.0 & $8.3^{\mathrm{a}}$ & $7.5^{\mathrm{a}}$ & $7.9^{\mathrm{a}}$ & $7.9^{\mathrm{a}}$ & $8.5^{\mathrm{a}}$ & $8.2^{\mathrm{a}}$ \\
\hline $\begin{array}{l}\text { Atrazine } \\
+ \text { Metolachlor }\end{array}$ & 1.5 & $6.0^{\mathrm{b}}$ & $5.4^{\mathrm{b}}$ & $5.7^{\mathrm{b}}$ & $5.9^{\mathrm{b}}$ & $5.4^{\mathrm{b}}$ & $5.7^{\mathrm{b}}$ \\
\hline $\begin{array}{l}\text { Atrazine } \\
+ \text { Metolachlor }\end{array}$ & 2.3 & $8.6^{\mathrm{a}}$ & $9.0^{\mathrm{a}}$ & $8.8^{\mathrm{a}}$ & $8.3^{\mathrm{a}}$ & $8.8^{\mathrm{a}}$ & $8.6^{\mathrm{a}}$ \\
\hline $\begin{array}{l}\text { Atrazine } \\
+ \text { Bromoxynil }\end{array}$ & 2.1 & $7.2^{\mathrm{a}}$ & $7.4^{\mathrm{a}}$ & $7.3^{\mathrm{a}}$ & $6.8^{\mathrm{b}}$ & $7.0^{\mathrm{a}}$ & $7.0^{\mathrm{a}}$ \\
\hline $\begin{array}{l}\text { Atrazine } \\
+ \text { Bromoxynil }\end{array}$ & 2.3 & $9.1^{\mathrm{a}}$ & $9.0^{\mathrm{a}}$ & $9.1^{\mathrm{a}}$ & $8.6^{\mathrm{a}}$ & $8.9^{\mathrm{a}}$ & $8.8 \mathrm{a}$ \\
\hline
\end{tabular}


Vol. 5, No. 04; 2020

ISSN: $2456-8643$

\begin{tabular}{|c|c|c|c|c|c|c|c|}
\hline $\begin{array}{l}\text { Hoe weeding at } 4 \\
\text { and } 8 \text { WAS }\end{array}$ & & $5.3^{\mathrm{b}}$ & $5.6^{\mathrm{b}}$ & $5.5^{\mathrm{b}}$ & $5.6^{\mathrm{bc}}$ & $5.9^{\mathrm{b}}$ & $5.8^{\mathrm{b}}$ \\
\hline Weedy check & & $1.3^{\mathrm{c}}$ & $1.5^{\mathrm{c}}$ & $1.4^{\mathrm{c}}$ & $1.3^{\mathrm{c}}$ & $1.0^{\mathrm{c}}$ & $1.2^{\mathrm{c}}$ \\
\hline $\mathrm{SE} \pm$ & & 0.21 & 0.24 & 0.22 & 0.23 & 0.20 & 0.9 \\
\hline \multirow[t]{5}{*}{$\begin{array}{l}\text { Sheep } \\
\text { (SM) }\end{array}$} & $\mathrm{t} / \mathrm{ha}$ & & & & & & \\
\hline & 0 & $3.1^{\mathrm{c}}$ & $2.8^{\mathrm{c}}$ & $2.9^{c}$ & $3.0^{c}$ & $2.6^{c}$ & $2.8^{\mathrm{d}}$ \\
\hline & 2 & $5.1^{\mathrm{b}}$ & $4.6^{\mathrm{b}}$ & $4.9^{\mathrm{b}}$ & $4.8^{\mathrm{c}}$ & $5.0^{\mathrm{b}}$ & $4.9^{c}$ \\
\hline & 4 & $8.0^{\mathrm{a}}$ & $7.1^{\mathrm{a}}$ & $7.6^{\mathrm{a}}$ & $6.4^{\mathrm{b}}$ & $7.2^{\mathrm{a}}$ & $6.8^{\mathrm{b}}$ \\
\hline & 6 & $8.5^{\mathrm{a}}$ & $8.0^{\mathrm{a}}$ & $8.3^{\mathrm{a}}$ & $8.3^{\mathrm{a}}$ & $8.0^{\mathrm{a}}$ & $8.2^{\mathrm{a}}$ \\
\hline $\mathrm{SE} \pm$ & & 0.19 & 0.16 & 0.16 & 0.13 & 0.15 & 0.11 \\
\hline \multicolumn{8}{|l|}{ Interaction } \\
\hline WC*SM & & NS & NS & NS & NS & NS & NS \\
\hline
\end{tabular}

Means in a column of any set of treatments followed by dissimilar letter(s) are significantly different at $\mathrm{p} \leq 0.05$ using DMRT

Plant stem girth measured showed significant $(\mathrm{p}<0.05)$ difference among the weed control treatments and sheep manure application evaluated during 2015 and 2016 cropping seasons (Table 7). Weedy check plots produced significantly $(\mathrm{p}<0.05)$ the least plant girth in comparison to other weed control treatments applied. Smaller plant girth resulted from plants in plots treated with Codal Gold and atrazine + metolachlor at $1.5 \mathrm{~kg}$ a.i/ha each. Maize plants from plots that received atrazine + bromoxynil and atrazine + metolachlor at $2.3 \mathrm{~kg}$ a.i/ha each and Codal Gold at $2.0 \mathrm{~kg}$ a.i/ha maintained significantly higher stem girth in both 2015 and 2016 cropping seasons which were comparable to plants in plots treated with $2.1 \mathrm{~kg}$ a.i/ha of atrazine + bromoxynil and hoe weeded plots. Maize plants in plots that received sheep manure had higher stem girth compared to plants in plots that did not receive the manure treatments. Maize plants in plots to which 6t/ha of sheep manure was applied produced the highest stem girth of $8.3 \mathrm{~cm}$ in both seasons. Plants in plots treated with $2.3 \mathrm{~kg}$ a.i $/$ ha of atrazine + metolachlor and those that received $6 \mathrm{t} / \mathrm{ha}$ of sheep manure significantly produced the longest cob (Table 8). Cob length obtained from plots to which $2.3 \mathrm{~kg}$ a.i/ha of atrazine + metolachlor was applied was at par with those got from atrazine + bromozynil treated plots at $2.3 \mathrm{~kg}$ a.i/ha. Shortest cob length was obtained from plants in the weedy check plots as well as in plots that did not have a supply of sheep manure. The largest maize cob was produced in plots treated with atrazine + bromoxynil at $2.3 \mathrm{~kg}$ a.i/ha. And this was comparable to cob diameters obtained from other weed control treatment plots except plots treated with Codal Gold and atrazine + metolachlor at $1.5 \mathrm{~kg}$ a.i $/ \mathrm{ha}$ 
each and the weedy check (Table 8). The weedy check plots consistently gave the least cob diameter in both seasons. The largest cob diameter was obtained in plots where sheep manure was applied at 6t/ha. However, in 2015 cropping season, cob diameters obtained in plots treated with $4 \mathrm{t}$ and $6 \mathrm{t} / \mathrm{ha}$ of sheep manure were similar.

In both seasons, crops that received $2.3 \mathrm{~kg}$ a.i/ha of atrazine + bromoxynil produced the highest grain yield which was statistically comparable to crops treated with other weed control measures except those that received Codal Gold and atrazine + metolachlor at $1.5 \mathrm{~kg}$ a.i/ha each as well as crops in the weedy check plots. Higher grain yields were obtained from crops in plots that received higher doses of the herbicides. And this was closely followed by crops grown in plots that were weeded twice. Higher grain yields resulted from crops in plots that received 6t/ha of sheep manure. Poor grain yields were obtained in plots that did not receive sheep manure as well as crops in the weedy check plots.

Table 7. Effect of weed control treatments and sheep manure on plant height and stem girth of maize in Anyigba during 2015 and 2016 cropping seasons

\begin{tabular}{|c|c|c|c|c|c|c|c|}
\hline $\begin{array}{l}\text { Weed control } \\
\text { (WC) } \\
\text { treatments }\end{array}$ & $\begin{array}{l}\text { Rate } \\
\text { (kga.i/ha) }\end{array}$ & $\begin{array}{l}\text { Plant } \\
\text { height }(\mathrm{cm}) \\
2015\end{array}$ & $\begin{array}{l}\text { Plant } \\
\text { height }(\mathrm{cm}) \\
2016\end{array}$ & Mean & $\begin{array}{l}\text { Stem } \\
\text { girth (cm) } \\
2015\end{array}$ & $\begin{array}{l}\text { Stem } \\
\text { girth }(\mathrm{cm}) \\
2016\end{array}$ & Mean \\
\hline Codal Gold & 1.5 & $220.0^{\mathrm{a}}$ & $218.4^{\mathrm{a}}$ & $219.2^{\mathrm{a}}$ & $3.9^{\mathrm{b}}$ & $4.0^{\mathrm{b}}$ & $3.9^{\mathrm{b}}$ \\
\hline Codal Gold & 2.0 & $219.3^{\mathrm{a}}$ & $215.9^{\mathrm{a}}$ & $217.6^{\mathrm{a}}$ & $8.3^{\mathrm{a}}$ & $8.1^{\mathrm{a}}$ & $8.2^{\mathrm{a}}$ \\
\hline $\begin{array}{l}\text { Atrazine } \\
+ \text { Metolachlor }\end{array}$ & 1.5 & $217.6^{\mathrm{a}}$ & $213.0^{\mathrm{a}}$ & $215.3^{\mathrm{a}}$ & $4.6^{\mathrm{b}}$ & $4.0^{\mathrm{b}}$ & $4.3^{b}$ \\
\hline $\begin{array}{l}\text { Atrazine } \\
+ \text { Metolachlor }\end{array}$ & 2.3 & $219.0^{\mathrm{a}}$ & $215.8^{\mathrm{a}}$ & $217.4^{\mathrm{a}}$ & $8.3^{\mathrm{a}}$ & $8.0^{\mathrm{a}}$ & $8.2^{\mathrm{a}}$ \\
\hline $\begin{array}{l}\text { Atrazine } \\
+ \text { Bromoxynil }\end{array}$ & 2.1 & $217.0^{\mathrm{a}}$ & $215.0^{\mathrm{a}}$ & $216.0^{\mathrm{a}}$ & $7.4^{\mathrm{a}}$ & $7.6^{\mathrm{a}}$ & $7.5^{\mathrm{a}}$ \\
\hline $\begin{array}{l}\text { Atrazine } \\
+ \text { Bromoxynil }\end{array}$ & 2.3 & $217.0^{\mathrm{a}}$ & $217.3^{\mathrm{a}}$ & $217.2^{\mathrm{a}}$ & $8.5^{\mathrm{a}}$ & $8.5^{\mathrm{a}}$ & $8.5 \mathrm{a}$ \\
\hline $\begin{array}{l}\text { Hoe weeding } \\
\text { at } 4 \text { and } 8 \\
\text { WAS }\end{array}$ & & $218.3^{\mathrm{a}}$ & $215.6^{\mathrm{a}}$ & $217.0^{\mathrm{a}}$ & $7.3^{\mathrm{a}}$ & $7.0^{\mathrm{a}}$ & $7.2 \mathrm{a}$ \\
\hline Weedy check & & $102.3^{b}$ & $110.6^{\mathrm{b}}$ & $106.5^{b}$ & $1.2^{\mathrm{c}}$ & $2.0^{\mathrm{c}}$ & $1.6^{\mathrm{c}}$ \\
\hline $\mathrm{SE} \pm$ & & 2.4 & 2.6 & 1.5 & 0.13 & 0.15 & 0.11 \\
\hline
\end{tabular}


Sheep t/ha manure (SM)

SE \pm

$\begin{array}{lllllll}0 & 154.7^{\mathrm{b}} & 143.7^{\mathrm{b}} & 149.2^{\mathrm{b}} & 3.8^{\mathrm{c}} & 3.0^{\mathrm{c}} & 3.4^{\mathrm{c}} \\ 2 & 210.3^{\mathrm{a}} & 215.0^{\mathrm{a}} & 212.7^{\mathrm{a}} & 5.1^{\mathrm{b}} & 4.9^{\mathrm{b}} & 5.0^{\mathrm{b}} \\ 4 & 219.4^{\mathrm{a}} & 217.0^{\mathrm{a}} & 218.2^{\mathrm{a}} & 8.0^{\mathrm{a}} & 8.0^{\mathrm{a}} & 8.0^{\mathrm{a}} \\ 6 & 219.0^{\mathrm{a}} & 217.8^{\mathrm{a}} & 218.4^{\mathrm{a}} & 8.2^{\mathrm{a}} & 8.3^{\mathrm{a}} & 8.3^{\mathrm{a}}\end{array}$

Interaction

$\mathrm{WC} * \mathrm{SM}$

$$
1.2
$$

1.4

1.0

0.10

0.12

0.04

Means in a column of any set of treatments followed by dissimilar letter(s) are significantly different at $\mathrm{p} \leq 0.05$ using DMRT

Table 8. Effect of weed control treatments and sheep manure on cob length, cob diameter and grain yield of maize in Anyigba during 2015 and 2016 cropping seasons

\begin{tabular}{|c|c|c|c|c|c|c|c|c|c|c|}
\hline $\begin{array}{l}\text { WC } \\
\text { treatments }\end{array}$ & $\begin{array}{l}\text { Rate } \\
\text { (kga.i/ha } \\
\text { ) }\end{array}$ & $\begin{array}{l}\text { Cob } \\
\text { length } \\
\text { (cm) } \\
2015\end{array}$ & $\begin{array}{l}\text { Cob } \\
\text { length } \\
(\mathrm{cm}) \\
2016\end{array}$ & $\begin{array}{l}\text { Mea } \\
\mathrm{n}\end{array}$ & $\begin{array}{l}\text { Cob } \\
\text { diamete } \\
\mathrm{r} \quad(\mathrm{cm}) \\
2015\end{array}$ & $\begin{array}{l}\text { Cob } \\
\text { diamete } \\
\mathrm{r} \quad(\mathrm{cm}) \\
2016\end{array}$ & $\begin{array}{l}\text { Mea } \\
n\end{array}$ & $\begin{array}{l}\text { Grain } \\
\text { yield } \\
(\mathrm{kg} / \mathrm{ha}) \\
2015\end{array}$ & $\begin{array}{l}\text { Grain } \\
\text { yield } \\
(\mathrm{kg} / \mathrm{ha}) \\
2016\end{array}$ & Mean \\
\hline Codal Gold & 1.5 & $29.3^{\mathrm{b}}$ & $27.1^{\mathrm{b}}$ & $28.2^{\mathrm{b}}$ & $4.0^{\mathrm{b}}$ & $4.0^{\mathrm{b}}$ & $4.0^{\mathrm{b}}$ & $3414^{\mathrm{d}}$ & $3128^{\mathrm{d}}$ & $3271^{\mathrm{c}}$ \\
\hline Codal Gold & 2.0 & $27.2^{\mathrm{b}}$ & $31.3^{\mathrm{a}}$ & $29.3^{b}$ & $5.3^{\mathrm{a}}$ & $5.1^{\mathrm{a}}$ & $5.2^{\mathrm{a}}$ & $4693^{b}$ & $4485^{b}$ & $4589^{b}$ \\
\hline $\begin{array}{l}\text { Atrazine + } \\
\text { Metolachlor }\end{array}$ & 1.5 & $24.7^{\mathrm{c}}$ & $26.3^{\mathrm{b}}$ & $25.5^{\mathrm{c}}$ & $3.8^{\mathrm{b}}$ & $3.6^{\mathrm{b}}$ & $3.7^{\mathrm{b}}$ & $2978^{\mathrm{e}}$ & $3204^{c}$ & $3091^{\mathrm{d}}$ \\
\hline $\begin{array}{l}\text { Atrazine + } \\
\text { Metolachlor }\end{array}$ & 2.3 & $33.0^{\mathrm{a}}$ & $32.8^{\mathrm{a}}$ & $33.0^{\mathrm{a}}$ & $5.5^{\mathrm{a}}$ & $5.4^{\mathrm{a}}$ & $5.5^{\mathrm{a}}$ & $4810^{\mathrm{a}}$ & $4602^{\mathrm{a}}$ & $4706^{a}$ \\
\hline $\begin{array}{l}\text { Atrazine } \\
+ \text { Bromoxyni } \\
1\end{array}$ & 2.1 & $32.2^{\mathrm{a}}$ & $30.9^{\mathrm{a}}$ & $31.6^{\mathrm{a}}$ & $5.3^{\mathrm{a}}$ & $5.2^{\mathrm{a}}$ & $5.3^{\mathrm{a}}$ & $4758^{\mathrm{a}}$ & $4400^{\mathrm{b}}$ & $4579^{\mathrm{b}}$ \\
\hline $\begin{array}{l}\text { Atrazine } \\
+ \text { Bromoxyni } \\
1\end{array}$ & 2.3 & $32.4^{\mathrm{a}}$ & $32.6^{\mathrm{a}}$ & $32.5^{\mathrm{a}}$ & $5.7^{\mathrm{a}}$ & $5.8^{\mathrm{a}}$ & $5.8^{\mathrm{a}}$ & $4819^{\mathrm{a}}$ & $4695^{\mathrm{a}}$ & $4757^{\mathrm{a}}$ \\
\hline $\begin{array}{l}\text { Hoe weeding } \\
\text { at } 4 \text { and }\end{array}$ & & $29.4^{\mathrm{b}}$ & $27.0^{\mathrm{b}}$ & $28.2^{\mathrm{b}}$ & $5.1^{\mathrm{a}}$ & $5.0^{\mathrm{a}}$ & $5.1^{\mathrm{a}}$ & $4498^{c}$ & $4653^{\mathrm{a}}$ & $4576^{\mathrm{b}}$ \\
\hline
\end{tabular}


Vol. 5, No. 04; 2020

ISSN: $2456-8643$

\begin{tabular}{|c|c|c|c|c|c|c|c|c|c|c|}
\hline \multicolumn{11}{|l|}{$8 \mathrm{WAS}$} \\
\hline $\begin{array}{l}\text { Weedy } \\
\text { check }\end{array}$ & & $8.9^{\mathrm{d}}$ & $11.4^{\mathrm{c}}$ & $10.2^{\mathrm{d}}$ & $1.8^{\mathrm{c}}$ & $1.3^{\mathrm{c}}$ & $1.6^{\mathrm{c}}$ & $473^{\mathrm{f}}$ & $514^{\mathrm{e}}$ & $494^{\mathrm{e}}$ \\
\hline SE \pm & & 1.17 & 1.20 & 1.14 & 0.16 & 0.14 & 0.11 & 42.8 & 47.5 & 31.0 \\
\hline \multirow{5}{*}{$\begin{array}{l}\text { Sheep } \\
\text { manure } \\
\text { (SM) }\end{array}$} & $\mathrm{t} / \mathrm{ha}$ & & & & & & & & & \\
\hline & 0 & $10.3^{c}$ & $11.7^{\mathrm{c}}$ & $11.0^{\mathrm{c}}$ & $2.3^{\mathrm{c}}$ & $2.6^{\mathrm{c}}$ & $2.5^{\mathrm{c}}$ & $605^{c}$ & $445^{\mathrm{c}}$ & $525^{\mathrm{c}}$ \\
\hline & 2 & $23.1^{\mathrm{b}}$ & $25.0^{\mathrm{b}}$ & $24.1^{\mathrm{b}}$ & $4.2^{\mathrm{b}}$ & $4.3^{\mathrm{b}}$ & $4.3^{\mathrm{b}}$ & $2261^{b}$ & $2558^{\mathrm{b}}$ & $2410^{b}$ \\
\hline & 4 & $34.7^{\mathrm{a}}$ & $36.0^{\mathrm{a}}$ & $35.4^{\mathrm{a}}$ & $7.6^{\mathrm{a}}$ & $7.4^{\mathrm{a}}$ & $7.5^{\mathrm{a}}$ & $4797^{\mathrm{a}}$ & $4993^{a}$ & $4895^{\mathrm{a}}$ \\
\hline & 6 & $36.0^{\mathrm{a}}$ & $36.9^{\mathrm{a}}$ & $36.5^{\mathrm{a}}$ & $7.6^{\mathrm{a}}$ & $7.8^{\mathrm{a}}$ & $7.7^{\mathrm{a}}$ & $4875^{\mathrm{a}}$ & $4971^{\mathrm{a}}$ & $4923^{\mathrm{a}}$ \\
\hline $\mathrm{SE} \pm$ & & 0.20 & 0.23 & 0.15 & 0.10 & 0.09 & 0.02 & 33.3 & 39.6 & 29.7 \\
\hline \multicolumn{11}{|c|}{ Interaction } \\
\hline $\mathrm{WC} * \mathrm{~S}$ & & NS & NS & NS & NS & NS & NS & NS & NS & NS \\
\hline
\end{tabular}

WC: Weed control, Means in a column of any set of treatments followed by dissimilar letter(s) are significantly different at $\mathrm{p} \leq 0.05$ using DMRT

\section{DISCUSSION}

Weed infestation was significantly low in herbicide treated plots indicating the efficacy of the herbicides applied especially at higher doses. This culminated in reduced weed biomass and indeed weed dry matter as exemplified in plots that received particularly atrazine + metolachlor and atrazine+bromoxynil at $2.3 \mathrm{~kg}$ a.i/ha each in the two years of study. Corroborating this finding, [12] reported depressed weed dry matter in plots to which herbicides were applied in the course of crop production. Herbicides were able to suppress weeds much more sufficiently compared to the hoe weeded and the weedy check plots owing to the broad spectrum activities of the herbicide mixtures. The synergy of the herbicide mixtures enhanced the spectrum of weeds controlled, hence the improved crop performance in the treated plots. Efficient and broad spectrum weed control using atrazine mixtures with other herbicides had green reported by [13, 14] while [15] affirmed the effectiveness of Codal Gold in containing weed menace in maize. Crops in plots that had adequate weed control produced higher crop vigour in contrast to those in the weedy check plots. Similarly, crops in plots that received atrazine + bromoxynil and atrazine + metolachlor at $2.3 \mathrm{~kg}$ a.i $/$ ha each produced the longest and largest cobs as well as the highest grain yield in all the seasons of the trial. This performance could be attributed to the optimal utilization of the available plant growth resources on account of little or complete absence of 
competition for those resources with weeds. This is in agreement with the findings of [16, 17] who reported impressive growth and yield parameters of maize in a severely depressed weed situation during the critical period of weed interference. In this research work, plots to which 6t/ha of sheep manure was applied produced outstandingly impressive grain yield owing to improved fertility status of the soil. It has been reported that organic manure helps to boost crop productivity as corroborated by [18] who stated that organic matter incorporated into soil results in the release of plant utilizable forms of nutrient elements which are utilized by crop plants in growth and developmental processes.

\section{CONCLUSION}

From the results obtained in this study, it can be concluded that the use of atrazine + bromoxynil at $2.3 \mathrm{~kg}$ a.i/ha as well as the application of sheep manure at $6 \mathrm{t} / \mathrm{ha}$ be encouraged amongst maize growers in order to boost the level of maize production in the derived guinea savanna zone of Nigeria

\section{ACKNOWLEDGEMENT}

The author wishes to thank the University management for providing the materials and supports required in carrying out the trials for the two seasons.

\section{REFERENCES}

References

1. [USDA] United State Department of Agriculture (2014). Key to Soil Taxonomy. Soil Conservation Series, Sixth Edition.

2. Kowal, J.A., Kassam, M., Dagg, M.N., Harrison, B.T., (1995). Maize in West Africa and its potential in savanna areas-World Crops, 27 (2): 73-78.

3. [FAO] Food and Agricultural Organization of the United Nations., (2014). FAOSTAT Agricultural Data http:apps. Fao.org/page/form collection =Production Crops. Primary \& Do main $=$ Production $\&$ Servlet $=1 \&$ language $=$ E N \& hostname $=$ apps. fao.org $\&$ version $=$ default Accessed August 2003.

4. FAOSTAT, (2014). Food and Agricultural Organization of the United Nations (FAO). FAO Statistical Database from http://faostat. fao.org.

5. Lagoke, S.T.O. (1998). Herbicide evaluation for the control of weeds in maize at samaru. In Report on cereals research cropping scheme meeting held at IAR/ABU. Samaru, Zaria, Nigeria, pp 90-91.

6. Lombin, G., (1987). Towards efficiency of fertilizer use and development in Nigeria in proceedings of the National Fertilizer Seminar, Port Harcourt, pp 106-123.

7. Lagoke, S.T.O. (1978). Methods of controlling speargrass (Imperata cylindrica L. Beauv. ) in maize (Zea mays L.). Ph.D Thesis, Department of Agronomy, University of Ibadan, Nigeria, 410 pp.

8. Lagoke, S.T.O., Kataria, D.O. and Ogungbile, O.A., (1981). Potential for improved weed control practices in field crop production in the Nigerian savanna zone. Paper presented 
at the Seminar on Green Revolution in Nigeria IAR, Ahmadu Bello University, Zaria, Nigeria, September, 1981.27p.

9. Magani, I.E., (1990). Effect of period of weed interference and season long weed control on maize (Zea mays L.). M.Sc Thesis, Department of Agriculture, Ahmadu Bello University, Zaria, Nigeria, 93p.

10. Akobundu, I.O., (1987). Weed Science in the Tropics: Principles and practices. John Wiley and Sons Limited, 522p.

11. [FDA] Federal Department of Agriculture., (1994). Weed Control Recommendations for Nigeria. Weed Control Series No.3 Afrika-Link Communications, Ibadan. 119p.

12. Ishaya, D.B., Adesoji, A.G. Tunku, P. and Ainika, J.N., (2002). Evaluation of herbicides for weed control in maize in the Northern Guinea savanna of Nigeria. Nigerian Journal of Weed Science, 25: 96-104.

13. Mahadi, M.A., (2002). Evaluation of rice based herbicides in rice/maize mixture. Unpublished M.Sc.Thesis submitted to the Postgraduate school, Ahmadu Bello University, Zaria 90p.

14. Yahaya, S., (1993). An evaluation of preemergence herbicides for weed control in maize and okra mixture at Samaru, Nigeria. HND Project, College of Agriculture, Ahmadu Bello University, Zaria $84 \mathrm{p}$.

15. Singh, R.D., Venngopal, K., Gupta, R.K. and Singh, O.B., (1986). Weed competition studies and its control in Sikkim. Indian Journal of Weed Science, 18(1) 29-33.

16. Mahadi, M.A., Dadari, S.A., Tanimu, B. Kuchinda, N.C., Babaji, B. and Ishaya, D.B., (2012). Effect of weed control treatments and cowdung manure on yield of maize (Zea mays L.). Nigeria Journal of Weed Science, 25:70-81.

17. Pamplona, P.P., Pahm, K.E., Dogya, N.E., Tinapay, S.S. and Pagolima, E.J., (1990). The influence of fertilizer rate, population density and irrigation on the yield of corn and soyabeans. In: Proceedings of Yield Research, 93-103.

18. Agbede, O.O., (2009). Understanding Soil and plant nutrition. Salman Press and Company Nigeria Limited, Keffi, Nasarawa State, $49 \mathrm{p}$ 